\title{
SPIRIT PENGELOLAAN OJEK ON-LINE TERHADAP PENGEMBANGAN LEMBAGA PENDIDIKAN ISLAM
}

\author{
Muhammad Tang \\ Sekolah Tinggi Agama Islam Al-Furqan Makassar, Indonesia \\ E-mail: muhammadtang.mt78@gmail.com \\ Abdul Rahim \\ Institut Agama Islam Negeri Bone, Indonesia \\ E-mail: rahimilmi72@gmail.com \\ Baso \\ Sekolah Tinggi Agama Islam Al-Furqan Makassar, Indonesia \\ E-Mail: andiasoparakkasi@gmail.com
}

\begin{abstract}
Abstrak: Pengembangan lembaga pendidikan Islam sangat urgen untuk dilakukan sekarang ini, karena masih tertinggal dibandingkan dengan lembaga pendidikan umum lainnya. Lembaga Pendidikan Islam harus berbenah diri untuk merespon perkembangan zaman digital yang dikenal dengan era revolusi industri 4.0. Tulisan ini hadir untuk menggali, menafsirkan dan mendeskripsikan spirit atau nilai yang terkandung dalam ojek on-line (OJOL) untuk dijadikan landasan pengembangan lembaga Pendidikan Islam dalam era revolusi industri 4.0. Kemajuan alat informasi dan komunikasi yang teraplikasi dalam ojek on-line merupakan suatu kajian yang menarik untuk ditarik dalam dunia pendidikan. Metode yang digunakan dalam penelitian ini adalah metode kualitatifdeskreptif dengan berbasis kepada digital on-line research (media sosial). Hasil penelitian ini mengungkapkan bahwa spirit yang terkandung dalam Ojek On-Line yang dapat dijadikan sebagai landasan pengembangan lembaga pendidikan islam di antaranya, yaitu; (1) akses mudah dan terjangkau secara ekonomi, (2) pelayanan yang prima, (3) komponen sistem informasi yang lengkap, (4) membangun sistem jaringan (net working) yang luas, (5) memiliki banyak menu layanan/pilihan..
\end{abstract}

Kata kunci: Pengembangan Ojek Online, Transformasi, Lembaga Pendidikan Islam

\section{Pendahuluan}

Syair cinta yang masyhur di telinga kita, entah siapa yang pertama kali mengucapkannya, "dunia tak selebar daun kelor", syair ini telah terbantahkan oleh perkembangan zaman sekarang ini, "dunia selebar daun kelor", karena sekarang ini hanya dengan satu jentikan tangan kita bisa menjelajah ke bagian dunia yang kita inginkan. Kemajuan alat informasi, komunikasi, dan teknologi membuat kehidupan manusia serba mudah. Teori evolusi yang dikembangkan Morgan dalam Lauer, mengemukakan bahwa kemajuan kebudayaan sejalan dengan perkembangan teknologi. Semakin meningkat kontrol manusia atas kehidupannya melalui teknologi baru, semakin berkembang kebudayaanya.

Jauh sebelum lahir teori Morgan tersebut, spirit perubahan (transformasi) atau pengembangan (modernisasi), \pm 14 abad yang lalu telah diisyaratkan oleh Tuhan pencipta dan pengatur alam semesta ini lewat firmannya yang termaktub dalam salah satu kitab sucinya, yang

\footnotetext{
${ }^{1}$ Morgan dalam Robert H. Lauer, Perspectives on Social Change, Edisi kedua: terj. Alimanda S.U, Perspektif Tentang Perubahan Sosial, (Jakarta: PT Rineka Cipta, 1993), 389. 
menyatakan "...sesunngubnya Allah tidak mengubah keadaan suatu kaum sebelum mereka mengubah keadaannya...". Ayat ini memberikan dorongan kepada manusia untuk melakukan suatu perubahan/transformasi dalam kehidupannya. Allah SWT., tidak sekedar mendorong umat manusia untuk melakukan perubahan, tapi juga menyediakan segala perangkat, sarana dan alat perubahan tersebut. Mulai dari akal pikiran (yang tidak diberikan kepada makhluk Tuhan lainnya, sampai kepada anatomi tubuh yang memungkinkan dan memudahkan untuk bergerak dan beraktivitas dalam melakukan perubahan tersebut. Sumber daya alam melimpah yang disediakan oleh Tuhan sang pencipta merupakan suatu peluang sekaligus sebagai tantangan buat manusia untuk mengolahnya menjadi sesuatu yang bermanfaat bagi kehidupannya. Segala ciptaan Tuhan di muka bumi ini adalah untuk manusia, sesuai dengan firmannya, "Dialah (Allab) yang menciptakan segala apa yang ada di bumi untukmu...".

Di era digital sekarang ini yang biasa disebut dengan era revolusi industri 4.0 memiliki dampak yang cukup luas dalam masyarakat, baik terhadap pola pikirnya maupun terhadap pola prilaku atau tingkah laku masyarakat. Schwab dalam Dadang Nugraha mengemukakan bahwa, "the fourth industrial revolution will affect the very essence of our human experience" . Efek atau dampak yang paling esensi adalah perubahan pola pikir masyarakat pada umumnya ingin mendapatkan sesuatu serba instant dan cepat, serta ingin mendapatkan pelayanan yang bersifat prima (mudah, nyaman, ramah dan cepat).

Dalam merespon pola pikir dan pola prilaku masyarakat tersebut, kemajuan alat informasi dan komonikasi melahirkan berbagai aplikasi yang dapat diakses dengan mudah dan cepat. Termasuk dalam hal ini adalah pada bidang transportasi yang disebut dengan ojek on-line (OJOL), baik roda dua (motor) maupun roda empat (mobil). Sejak kehadiran OJOL tidak semua masyarakat meresponnya dengan baik, terutama menerima tantangan dari alat transportasi yang bersifat manual yang tidak siap bersaing. Namun, kehadiran OJOL sekarang ini tidak bisa dibendung lagi, karena menjadi tuntutan dan kebutuhan masyarakat yang ingin mendapatkan pelayanan yang cepat, mudah, dan terjangkau.

Kehadiran OJOL cukup menarik untuk dikaji, walaupun mendapat tantangan dari sebagaian masyarakat, tapi dapat berkembang dan maju sampai sekarang ini. Tentu OJOL memiliki spirit dan nilai yang terkandung dalam pengelolaannya yang dapat diadaptasi dalam pengelolaan pengembangan lembaga Pendidikan di era digital sekarang ini. Tulisan ini hadir untuk

\footnotetext{
${ }^{2}$ QS. al-A'raf (13): 11.

${ }^{3}$ Qs. Al-Baqarah (2): 29.

4 Schwab dalam Dadang Nugraha, "Transformasi Sistem Revolusi Industri 4.0, Workshop Technopreneurship “Road to TBIC 2019”, 30 September 2018), 3.
} 
membedah dan menafsirkan spirit yang terkandung dalam pengelolaan OJOL sebagai transformasi sosial dengan pendekatan kualitatif-deskriptif berbasis digital on-line research.

\section{Gojek dalam Tinjauan Historis}

Transportasi on-line yang berkembang di Indonesia sekarang ini yang dikenal umum oleh masyarakat adalah Go-Jek dan Grab. Walaupun sudah banyak transfortasi lainnya yang sebelumnya manual sekarang beralih kesistem on-line untuk mengikuti perkembangan zaman. GoJek dan Grab, kedua transformasi on-line ini memiliki sistem oprasional yang sama sehingga yang dijadikan fokus kajian mengambil salah satunya yaitu, Go-Jek. Dijadikannya fokus ini adalah untuk melihat, menafsirkan, menganalisis dan mendeskripsikan spirit dan nilai yang terkandung di dalam ojek on-line tersebut dijadikan landasan pengembangan lembaga Pendidikan Islam.

Go-Jek merupakan sebuah perusahaan transportasi asal Indonesia yang melayani angkutan manusia dan barang melalui jasa ojek. Perusahaan ini didirikan pada tahun 2010 di Jakarta oleh Nadiem Makarim warga negara Indonesia lulusan Master of Business Administration dari Harvard Business School. Pada tanggal 13 Oktober 2010, GO-JEK resmi berdiri dengan 20 orang pengemudi. Pada saat itu, GO-JEK masih mengandalkan call centre untuk menghubungkan penumpang dengan pengemudi ojek. Pada pertengahan 2014, berkat popularitas Uber kala itu, Nadiem Makarim mulai mendapatkan tawaran investasi. Pada 7 Januari 2015, GOJEK akhirnya meluncurkan aplikasi berbasis Android dan IOS untuk menggantikan sistem pemesanan menggunakan call center. ${ }^{5}$

Ide mendirikan Go-Jek muncul dari pengalaman pribadi Nadiem Makarim menggunakan transfortasi ojek hampir setiap hari ke tempat kerjanya menembus kemacetan di Jakarta. Nadiem melihat ternyata sebagian besar waktu yang dihabiskan oleh pengemudi ojek hanyalah sekedar mangkal menunggu penumpang. Padahal, pengemudi ojek akan mendapatkan penghaslan yang lumayan bila banyak penumpang. Seain itu, ia melihat ketersedian jenis transfortasi ini tidak sebanyak transfortasi lannnya sehingga seringkali cukup sulit untuk dicari. Ia menginginkan ojek yang yang bisa ada setiap saat dibutuhkan. Dari pengalan tersebut, Nadiem Makarim melihat adanya peluang untuk membuat sebuah layanan yang dapat menghubungkan penumpang dengan pengemudi ojek. ${ }^{6}$

Pada awal tahu 2015, Go-Jek telah meluncurkan sistem operasional berbasis pada aplikasi di ponsel Android dan iOS. Hal ini fenomena Go-Jek menjadi perbincangan baik pada tingkat regional maupun pada tingkat mancanegara seperti yang dilansir salah satu media mancanegara berikut ini:

\footnotetext{
${ }^{5}$ Lihat di id.techinasia.com, diakses tanggal, 20/12/2018.

${ }^{6}$ Lihat di Wikepedia, https://id.wikipedia.org/wiki/Gojek, diakses pada tanggal, 21/12/2018.

172 | Tarbiyatuna: Jurnal Pendidikan Islam; Volume 13, Nomor 2, Agustus 2020, $170-189$ p-ISSN: 2085-6539; e-ISSN: 2242-4579
} 
"Beberapa bulan lalu, perusahaan bernama GO-JEK, meluncurkan aplikasi yang memungkinkan user memesan ojek secara online. Aplikasi itu mengkalkulasi biaya perjalanan dan pengemudi akan menjemput penumpang di manapun," tulis media asal Amerika Serikat.

Berbagai perbincangan tentang Go-Jek yang menjadi fenomenal di era Industri 4.0 merupakan suatu respon yang bersifat alamiah (natural) untuk memenuhi kebutuhan masyarakat. Dalam masyarakat industri atau masyarakat konsumsi menurut istlilah Van Peursen (2018), memiliki mobilitas yang tinggi dan konpetitif yang ketat sehingga mendorong untuk bergerak cepat dan menginginkan pelayanan yang prima (cepat, nyaman, aman, muda, dan terjangkau). Karakter inilah yang melekat dalam Go-Jek dalam merespon kebutuhan masyarakat industri 4.0.

Perkembangnan Go-Jek di Indonesia mengalami perkembangan secara signifikan dengan menyediakan berbagai macam menu penyedian jasa. Go-Jek menawarkan 4 (empat) jasa layanan yang bisa dimanfaatkan oleh para pelanggannya: Instant Courier (pengantaran barang), Transport (jasa angkutan), Shopping (belanja) dan Corporate (Kerjasama dengan perusahaan untuk jasa kurir) yang menekankan keunggulan dalam kecepatan, inovasi dan interaksi sosial. Go-jek Juga menyediakan layanan pembayaran digital yaitu Go-pay, Layanan Go Jek juga memenuhi kebutuhan setiap hari, Saat ini Go-jek sedang Terus melakukan Ekspansi ke Negara - Negara di Asia Tenggara, dan kini sudah ada di Thailand dan Vietnam kabarnya Gojek akan merilis di Singapura dan Filipina. ${ }^{8}$

\section{Pendanaan}

Suatu lembaga atau perusahaan untuk menjadi besar dibutuhkan pendanaan yang kuat. GO-JEK pertama kali mendapatkan kucuran dana dari NSI Ventures pada Juni 2015 dengan besaran dana yang tidak dipublikasikan. Pada Oktober 2015, GO-JEK kembali mendapatkan kucuran dana. Kali ini dari Sequoia Capital dan DST Global yang juga tidak disebutkan jumlahnya. Pada Agustus 2016, GO-JEK secara resmi mengumumkan pendanaan senilai US\$550 juta atau sekitar Rp7,2 triliun dari KKR, Warburg Pincus, Farallon Capital, dan Capital Group Private Markets dan investor-investor sebelumnya. Dengan adanya pendanaan tersebut, GO-JEK resmi berstatus sebagai unicorn pertama di Indonesia, yaitu startup dengan valuasi lebih dari US $\$ 1$ miliar. Pada saat itu, valuasi GO-JEK telah mencapai US $\$ 1,3$ miliar (sekitar Rp17 triliun). ${ }^{9}$

Pada Januari 2018, Google melalui situs blog resminya mengumumkan bahwa mereka telah memberikan pendanaan untuk G0-JEK. Ini merupakan investasi pertama Google kepada startup di Asia. Kucuran dana tersebut merupakan bagian dari seri pendanaan yang diikuti

\footnotetext{
${ }^{7}$ Lihat Global Post, diakses pada tanggal 21/12/2018.

${ }^{8}$ Lihat Wikepedia, https://id.wikipedia.org/wiki/Gojek, diakses pada tanggal 30/12/2018.

${ }^{9}$ Lihat id.techinasia.com, diakses tanggal 30/12/2018.
} 
oleh Tencent, JD, Temasek, dan Meituan-Dianping yang mencapai angka US\$1,2 miliar (sekitar Rp16 triliun). Dalam pengumumannya, Google tidak merinci besaran jumlah investasinya kepada GO-JEK namun sebuah sumber dari Reuters menyebutkan totalnya sekitar 100 juta dollar AS (sekitar 1,3 triliun). ${ }^{10}$

Setelah Google mengucurkan dana, pada 12 Februari 2018 Astra Internasional yang merupakan salah satu perusahaan otomotif nasional mengumumkan investasinya kepada GOJEK senilai US\$ 150 juta atau sekitar Rp2 triliun. Suntikan tersebut merupakan investasi terbesar sepanjang sejarah Astra di sektor digital dan yang terbesar di GO-JEK bila dibandingkan dengan investor-investor lainnya sampai pada saat itu. Pada hari yang sama, Djarum Grup melalui PT Global Digital Niaga (GDN) yang merupakan anak usaha perusahaan modal ventura Global Digital Prima (GDP) milik Djarum, juga mengumumkan investasinya kepada GO-JEK. Dalam pengumuman tersebut. GDN tidak bersedia mengungkapkan berapa dana yang mereka investasikan ke GO-JEK.

\section{Akuisisi}

Dalam upaya melakukan pengembangan aplikasinya, GO-JEK mengakuisisi beberapa perusahaan di India dan membuka kantor di Bengaluru, sebuah daerah yang terkenal sebagai "Silicon Valley nya India". Hubungan GO-JEK dengan India bermula pada April 2015, saat GO-JEK menyewa C42 Engineering, sebuah perusahaan rekayasa perangkat lunak selama dua bulan di Jakarta untuk membereskan kekutu (bug) dalam aplikasi mereka. Hubungan ini tercipta berkat Sequoia Capital yang merupakan salah satu investor GO-JEK. ${ }^{11}$

Februari 2016, GO-JEK akhirnya mengakuisisi C42 Engineering beserta CodeIgnition, perusahaan pengembangan aplikasi di New Delhi yang sebelumnya juga pernah bekerja untuk GO-JEK. Kedua perusahaan teknologi ini ditugaskan membantu meningkatkatkan sistem IT untuk menanggulangi jumlah pengguna yang semakin banyak. Pada saat itu, pertumbuhan GO-JEK melaju dengan cepat. Jumlah pengunduh aplikasinya mencapai 11 juta dengan 200 ribu sopir GO-JEK. Pada tahun yang sama, tepatnya pada September 2016 GO-JEK mengakusisi Pianta, sebuah startup lokal di India yang menyediakan layanan kesehatan seperti terapi fisik, perawat, hingga pengumpulan sampel untuk pemeriksaan di laboratorium. Menutup tahun 2016, GO-JEK mengakuisisi startup keempatnya di India yaitu LeftShift, perusahaan yang bergerak di bidang aplikasi Android, iOS, dan situs internet.

GO-JEK tidak ingin berhenti hanya sebagai perusahaan transportasi berbasis daring, namun bertransformasi sebagai sebuah perusahaan financial technology (fintech) melalui GO-

${ }^{10}$ Savithri, Agnes. "Google Akui Investasi ke Gojek". Teknologi, 2018.

${ }^{11}$ Lihat di tirto.id., diakses pada tanggal, 3/1/2019.

174 | Tarbiyatuna: Jurnal Pendidikan Islam; Volume 13, Nomor 2, Agustus 2020, $170-189$ p-ISSN: 2085-6539; e-ISSN: 2242-4579 
PAY. Pada akhir tahun 2016 GO-JEK mengakuisisi Ponselpay, sebuah perusahaan keuangan milik MVComerce yang telah memiliki lisensi uang elektronik (e-money) dari Bank Indonesia. GO-JEK membutuhkan lisensi tersebut guna mengembangkan GO-PAY yang telah mereka kembangkan untuk menjadi e-money layaknya Flazz milik BCA, Brizzi milik BRI, T-Cash milik Telkomsel dan lain-lain.

Pada 15 Desember 2017, GO-JEK mengumumkan akuisisinya terhadap tiga perusahaan financial technology yaitu Kartuku, Midtrans, dan Mapan untuk mendukung ekspansi GO-PAY di luar ekosistem GO-JEK. Kartuku merupakan sebuah perusahaan penyedia Prosesor Pihak Ketiga atau Third Party Processor (TPP) dan Penyedia Layanan Pembayaran (PSP). Kartuku yang telah mengoperasikan lebih dari 150 ribu alat pembayaran di gerai luring (offline) dan telah bekerjasama dengan sembilan bank acquirer ini, akan difokuskan untuk pengembangan penggunaan GO-PAY secara luring. ${ }^{12}$

Midtrans adalah salah satu perusahaan penyedia jasa pemprosesan pembayaran secara daring yang telah menjalin kemitraan dengan bank-bank di Indonesia, maskapai penerbangan, retail e-commerce dan perusahaan-perusahaan fintech. Sementara Mapan adalah jaringan layanan keuangan berbasis komunitas yang memungkinkan penggunanya mencicil barang yang mereka ingin beli dalam katalog barang Arisan Mapan. Mapan yang telah tersedia di 100 kota tersebut difokuskan oleh GO-JEK untuk mengakselerasi inklusi keuangan bagi masyarakat yang belum tersentuh layanan perbankan (unbanked). ${ }^{13}$

Pada 8 Agustus 2017, GO-JEK mengakuisisi LOKET, sebuah perusahaan yang bergerak di bidang event management \& ticketing. LOKET menghadirkan layanan pemesanan tiket secara daring, sampai menyediakan gelang RFID untuk pengunjung acara. Langkah ini diambil GO-JEK untuk mendorong perkembangan fitur penjualan tiket bioskop dan acara yang telah mereka miliki melalui GO-TIX. Pada tahun 2018, setelah sukses berekspansi ke Vietnam GO-JEK memperluas jaringan bisnisnya ke sektor periklanan. Kali ini, GO-JEK mengakuisisi Promogo, sebuah layanan pemasangan iklan di kendaraan pada September $2018 .^{14}$

\section{Kerja sama}

GO-JEK mengumumkan kerja sama dengan perusahaan taksi Blue Bird pada Mei 2016. Melalui kerja sama tersebut GO-JEK membuatkan aplikasi untuk pengemudi Blue Bird dan mulai Januari 2017 pengemudi Blue Bird bisa menerima pemesanan dari layanan GO-

\footnotetext{
${ }^{12}$ Lihat Wikipedia, https://id.wikipedia.org/wiki/Gojek, diakses pada tanggal 3/1/19.

${ }^{13}$ Dapat dilihat di katadata.news, diakses pada tanggal, 3/1/19.

${ }^{14}$ Lihat di kompas.com, diakses pada tanggal, 3/1/19.
} 
CAR milik GO-JEK. Pada Maret 2017, kedua perusahaan tersebut meningkatkan kerja samanya dengan meluncurkan fitur GO-Blue Bird. Melalui fitur tersebut, pengguna bisa langsung memesan taksi Blue Bird di aplikasi GO-JEK, tidak akan mendapatkan mitra pengemudi lain seperti hal nya ketika melalui GO-CAR.

\section{Dampak}

Sebuah riset yang dilakukan oleh Lembaga Demografi Fakultas Ekonomi dan Bisnis Universitas Indonesia menyebut GO-JEK telah memberi kontribusi Rp8,2 triliun per tahun bagi perekonomian Indonesia melalui penghasilan mitra pengemudi. GO-JEK juga berkontribusi Rp1,7 triliun per tahun bagi perekonomian Indonesia melalui penghasilan mitra UMKM. Penelitian yang melibatkan 3.315 responden di 9 wilayah tersebut menunjukkan ratarata penghasilan mitra pengemudi mencapai Rp3,31 juta lebih tinggi dari UMK 9 wilayah itu yang hanya Rp2,8 juta. (Andreas, Damianus. "Go-Jek Sumbang Rp8,2 Triliun Per Tahun ke Perekonomian Indonesia. ${ }^{15}$

\section{Ekspansi}

Pada 24 Mei 2018, GO-JEK mengumumkan kepastiannya untuk berekspansi ke empat negara di Asia Tenggara yaitu Vietnam, Thailand, Singapura, dan Filipina. GO-JEK mengaku menyiapkan dana sebesar USD500 juta atau sekitar Rp7,1 triliun untuk memuluskan langkahnya tersebut. Sebulan kemudian tepatnya pada 25 Juni 2018, GO-JEK memperkenalkan GO-Viet di Vietnam dan GET di Thailand sebagai bagian dari ekspansinya. ${ }^{16}$

Melihat sejarah lahir dan berkembamgnya ojek one-line Go-Jek tersebut memberikan gambaran bahwa perkembangan Go-Jek mulai dari inspirasi lahirnya, perkembangan jaringan dan jasa yang ditawarkan, dapat mengakuisisi beberapa perusahaan dalam negeri dan luar negeri, dan dapat melakukan ekspansi perusahaannya ke manca negara. Hal ini memberikan suatu inspirasi dan motivasi dalam pengembangan lembaga Pendidikan bagaimana spirit dan nilai yang terkandung dalam pengelolaan dalam Go-Jek tersebut.

\footnotetext{
${ }^{15}$ Lihat tirto.id. Diakses tanggal, 10/1/2019

${ }^{16}$ Tech in Asia Indonesia-Komunitas Online Startup di Asia". id.techinasia.com, diakses pada tanggal 10/1/2019. 


\section{Sistem Pengelolaan Go-Jek}

1. Fasilitas Go-Jek

Gambar 1. Menu Pelayanan Go-Jek

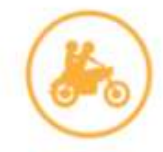

GO-RIDE

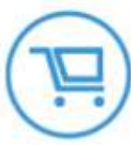

GO-MART

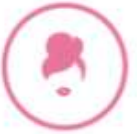

GO-GLAM

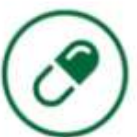

GO-MED

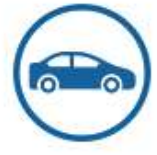

GO-CAR

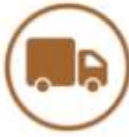

GO-BOX

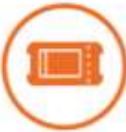

GO-TIX

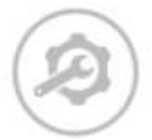

GO-AUTO

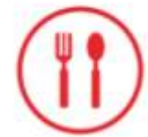

GO-FOOD

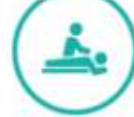

GO-MASSAGE

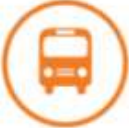

GO-BUSWAY

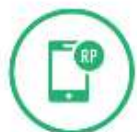

GO-PULSA

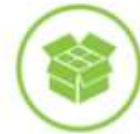

GO-SEND

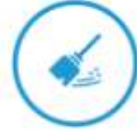

GO-CLEAN

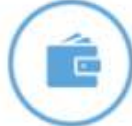

GO-PAY

a. Go-Ride

Layanan transportasi sepeda motor yang dapat mengantar Anda ke berbagai tempat, lebih mudah dan lebih cepat.

b. Go-Car

Layanan transportasi menggunakan mobil untuk mengantar Anda kemanapun dengan nyaman.

c. Go-Food

Layanan pesan antar makanan nomor 1 di Indonesia. Go-Jek memiliki lebih dari 30.000 daftar restoran

d. Go-Send

Layanan kurir instan yang dapat Anda gunakan untuk mengirim surat dan barang dalam waktu 60 menit.

e. G0-Mart

Layanan yang bisa Anda gunakan untuk berbelanja ribuan jenis barang dari berbagai macam toko. 
f. Go-Box

Layanan pindah barang ukuran besar menggunakan truk bak/blind van.

g. Go-Massage

Layanan jasa pijat kesehatan profesional langsung ke rumah Anda.

h. Go-Clean

Layanan jasa kebersihan profesional untuk membersihkan kamar kos, rumah dan kantor Anda.

i. Go-Glam

Layanan jasa perawatan kecantikan untuk manicure-pedicure, cream bath, waxing, dan lainnya langsung ke rumah Anda.

j. Go-Tix

Layanan informasi acara dengan akses pembelian dan pengantaran tiket langsung ke tangan Anda.

k. Go-Busway

Layanan untuk memonitor jadwal layanan bus TransJakarta dan memesan GO-RIDE untuk mengantar Anda ke sana.

1. Go-Pay

Layanan dompet virtual untuk transaksi Anda di dalam aplikasi GO-JEK.

m. Go-Med

Layanan terintegrasi untuk membeli obat-obatan, vitamin dan kebutuhan medis lainnya dari apotek berlisensi.

n. Go-Auto

Layanan auto care, auto service, dan towing \& emergency untuk memenuhi kebutuhan otomotif Anda.

o. Go-Pulsa

Layanan pengisian pulsa langsung dari aplikasi GO-JEK dengan menggunakan GO-PAY 


\section{Struktur Organisasi}

Gambar.2. Struktur Organisasi Pusat
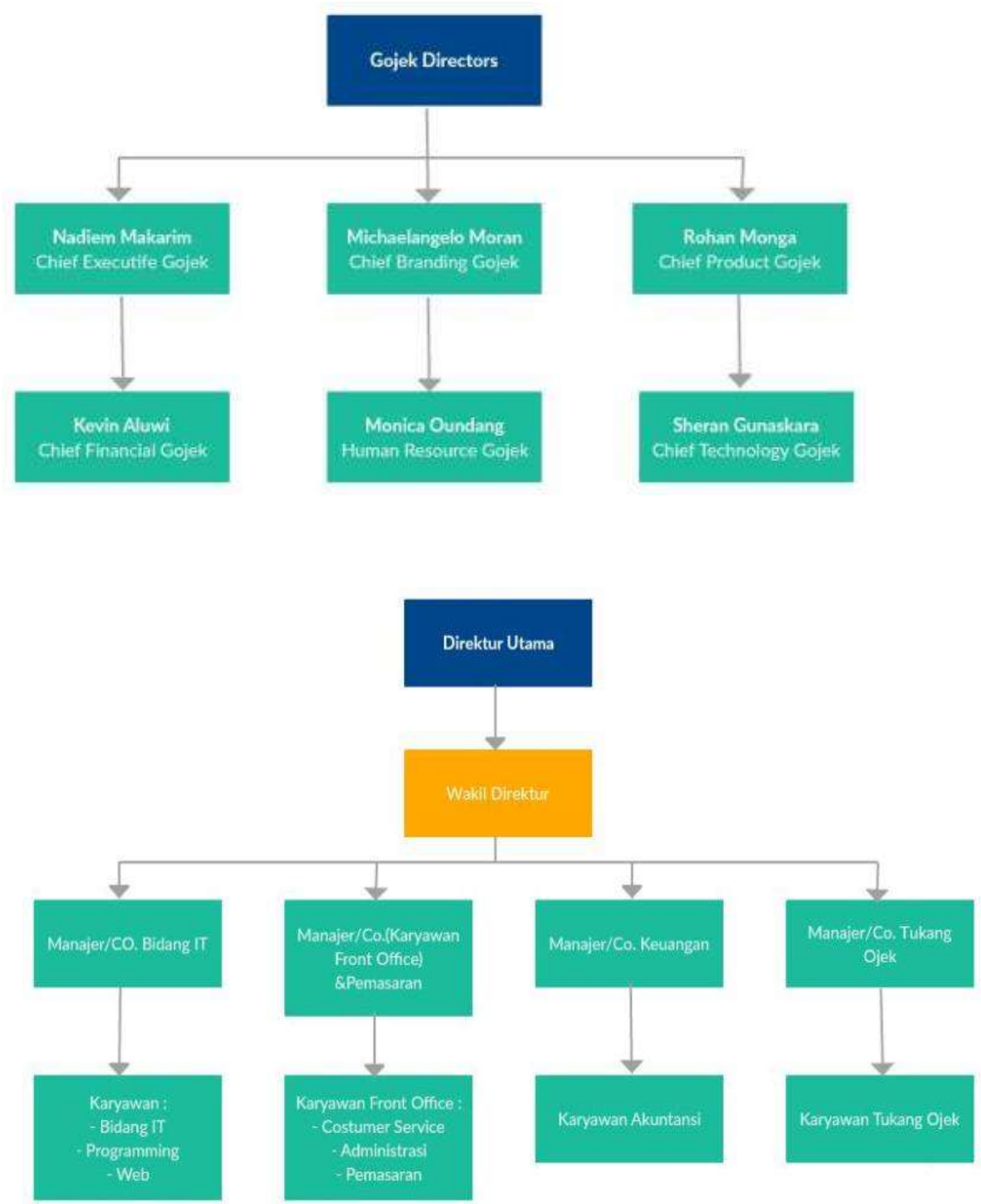

Gambar 3. Struktur Organisasi Regional 


\section{Pembagian Tugas}

1. Direktur Utama

a. Memutuskan dan menentukan peraturan dan kebijakan tertinggi perusahaan

b. Bertanggungjawab dalam memimpin dan menjalankan perusahaan

c. Bertanggung Jawab atas keuntungan dan juga kerugian yang dialami perusahaan

d. Merencanakan serta mengembangkan sember-sumber pendapatan dan pembelanjaan kekayaan perusahaan

e. Menentukan Strategi untuk mencapai Visi-Misi perusahaan

f. Mengkoordinasi dan mengawasi semua kegiatan perusahaan mulai bidang administrasi, kepegawaian hingga pengadaan barang

2. Wakil Direktur

Membantu Semua Tugas Direktur Utama yang merupakan wakil di masing-masing area

3. Manager IT

a. Mengembangkan dan menyusun strategi dan rencana IT Go-jek dalam hal mempermudah pekerjaan dan dalam pelayanan kepada pelanggan

b. Mengkoordinir dan mengelola pendayagunaan software, hardware, Brainware dan jaringan di bidang TIK untuk mencapai kinerja optimum Go-Jek Indonesia

c. Mengelola layanan perancangan sistem kompterisasi dan progam aplikasi perangkat yang terintegrasi

d. Menyediakan data-data yang diperlukan oleh Bagian lain yang menyangkut IT

4. Manager Karyawan Front Office \& Pemasaran

a. Melatih, menetapkan, melatih dan mengevaluasi karyawan front office.

b. Memastikan bahwasaanya karyawan mengetahui sistem komputerisasi, etika menerima keluhan secara langsung atau via telephon dan standard operasional Go-jek

c. Menangani keluhan pelanggan yang tidak bisa di selesaikan bawahannya

d. Membuat laporan daftar pelanggan

e. Menjaga kedisiplinan petugas kantor dengan memberikan sanksi dan peringatan bagi yang melanggar

f. Merencanakan dan menetapkan segala sesuatu yang berhubungan dengan pemasaran

5. Manager akuntansi

a. Mengkoordinasi perencanaan anggaran

b. Mengembangkan format pengajuan danpertanggungjawaban keuangan

c. Mengkoordinasi pelaksanaan audit

d. Melakukan sistem pencatatan keuangan 
e. Bertanggungjawab terhadap wakil direktur

f. Merencanakan mengendalikan dan membuat keputusan atas semua aktivitas akuntansi

g. Menerima laporan arus kas keluar dan masuk ke perusahaan

6. Manager Ojek

a. Membuat kelompok-kelompok tukang ojek

b. Mengkoordinir semua karyawan tukang ojek

c. Selalu melakukan pengontrolan di setiap lini pangkalan Go-jek.

d. Bertanggung jawab kepada wakil Direktur atas Semua Karyawan Tukang Ojek

7. Karyawan

a. Bidang programming

1) Melaksanakan semua pekerjaan yang ditetapkan oleh manajer IT di bidang Progaming

2) Bertanggungjawab mengenai progam kepada manajer IT.

b. Bidang Web

1) Melaksanakan semua pekerjaan yang ditetapkan oleh manajer IT di bidang Web

2) Bertanggungjawab mengenai program aplikasi maupun web go-jek

c. Front Office (CS, Administrasi \& Pemasaran)

1) Melaksanakan Semua pekerjaan Front Office yang ditetapkan oleh Manajer Front office dan administrasi

2) Bertanggung Jawab Kepada Manajer Front office dan administrasi

8. Tukang Ojek / Driver

a. Melaksanakan Semua Pekerjaan yang ditetapkan oleh manajer Bagian Ojek

b. Mengantarkan penumpang dan pesanan sesuai dengan waktu ditetapkan dan menjaga hubungan baik dengan pelanggan

c. Bertanggung jawab kepada atasannya

\section{Komponen Sistem Informasi}

Gambar 4. Komponen Sistem Informasi

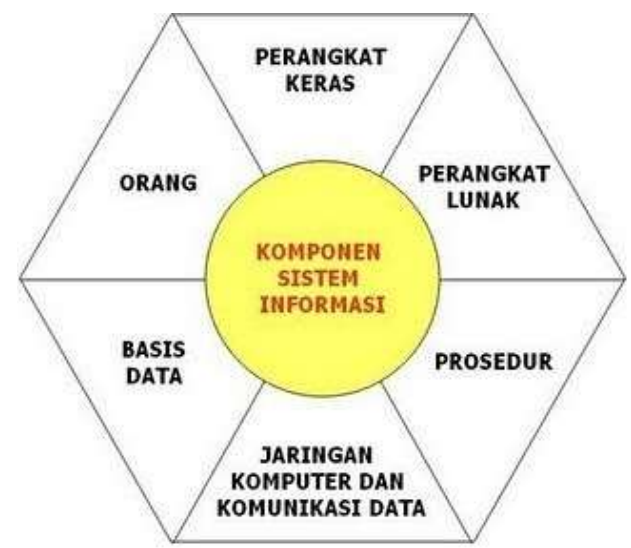


1. Perangkat Lunak : merupakan komponen yang memungkinkan hardware untuk memproses data melalui prosedur dan jaringan komunikasi yang sudah ditentukan. Go-Jek menawarkan perangkat lunak berupa aplikasi Android, IOS, dan juga Website. Sehingga user dapat terhubung dan memanfaatkan sistem informasi yang ada.

2. Perangkat Keras : merupakan piranti-piranti fisik dimana perangkat lunak berada. Go-Jek menggunakan Smartphone sebagai perangkat keras yang nantinya dipasang berupa aplikasi Go-Jek oleh user.

3. People : merupakan semua pihak yang bertanggung jawab dalam pengembangan sistem informasi, pemrosesan, dan penggunaan data. Dalam Go-Jek terdapat pihak-pihak sebagai berikut : Programmer, System Analyst, Administrator Database, Driver atau suksesor layanan lainnya, User / Penumpang, dan lain lain.

4. Basisdata / Data : Komponen informasi yang disimpan secara sistematik, sehingga dapat digunakan untuk menunjang kegiatan perusahaan. Pada Go-Jek antara lain adalah data penumpang, data driver, koordinat lokasi, data Go-Pay, dan lain-lain.

5. Jaringan Komputer : merupakan media yang menghubungkan seluruh komponen secara bersama. Go-Jek menggunakan jaringan internet, sehingga dapat menghubungkan pengguna atau klien dengan sistem informasi mereka yang berbasis cloud.

6. Prosedur : Sekumpulan aturan yang dipakai untuk mewujudkan pemrosesan data dan kesesuaian keluaran yang dikehendaki. Hal-hal yang menyangkut sistematika proses dalam aplikasi Go-Jek, seperti SOP Pemesanan, SOP Pembayaran, SOP Rekruitmen, dan lain-lain

\section{Klasifikasi Sistem Informasi yang digunakan}

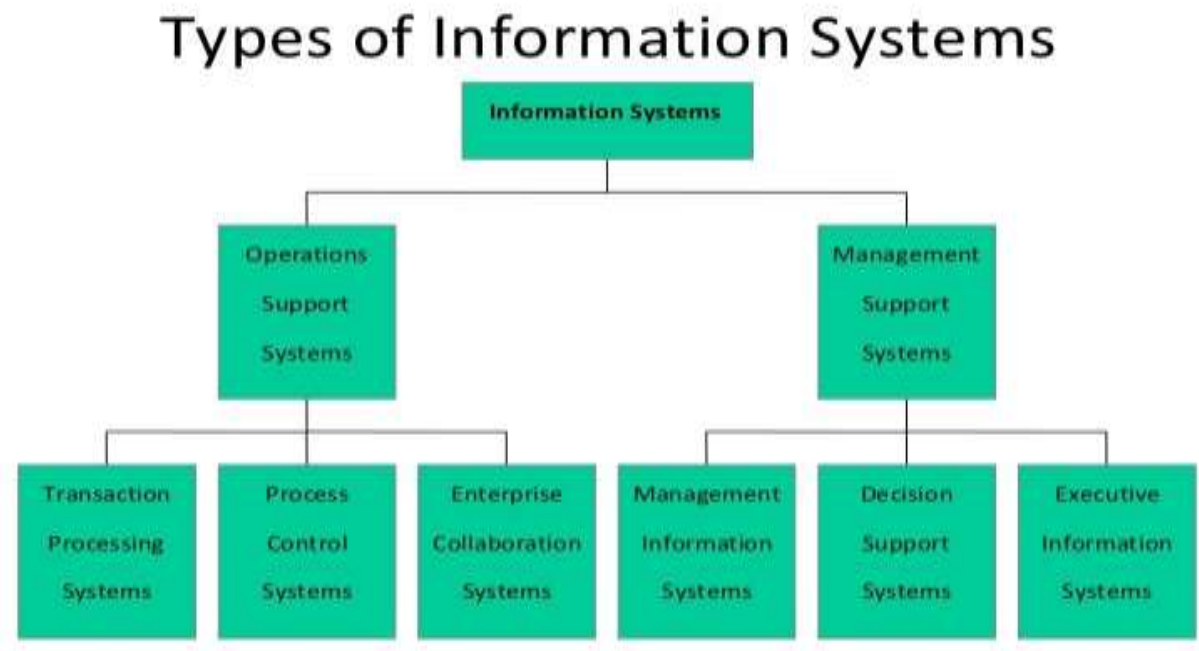

Gambar 5. e-tipe Sistem Informasi 
Gambar 6. Transaction Processing Systems

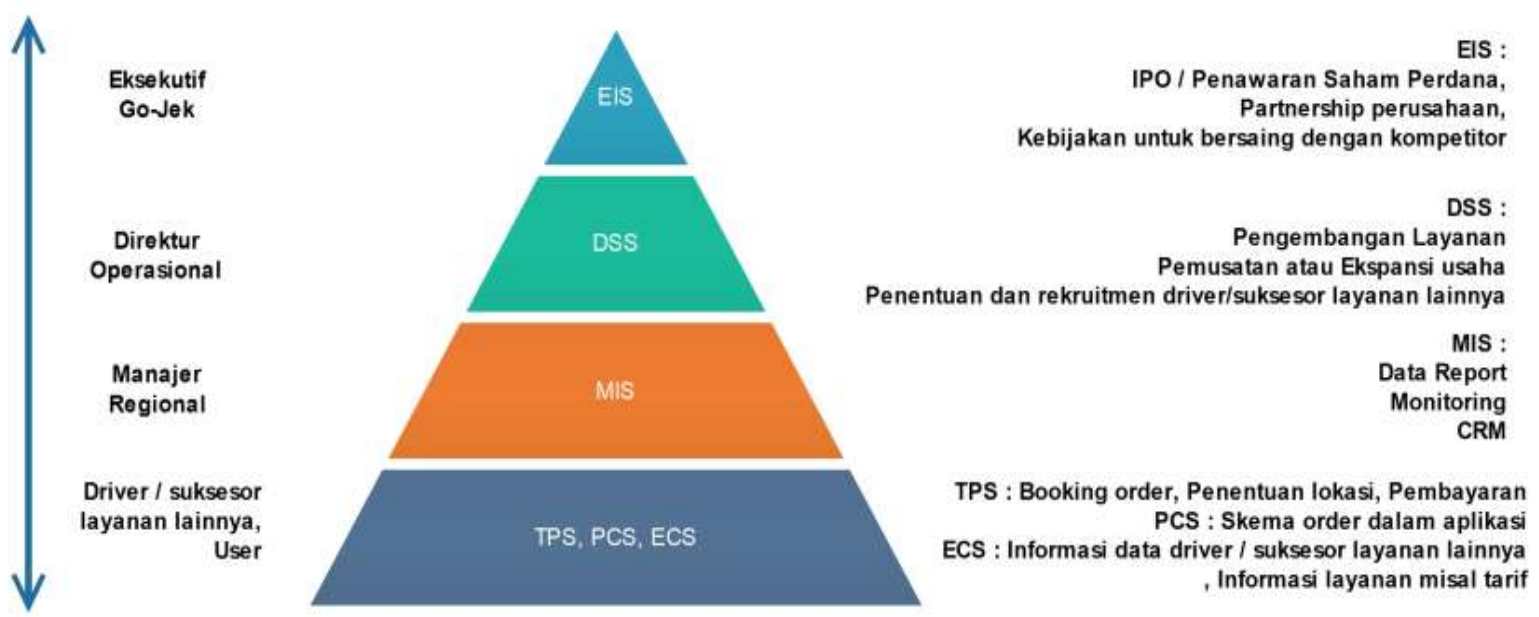

\section{Sistem Informasi untuk Pengambilan Keputusan Manajemen}

1. Management Information System (MIS)

MIS menyediakan laporan informasi bagi pihak manajemen. MIS dihasilkan dari data yang dihimpun dari operasi bisnis. MIS menyajikan informasi yang detail dan rangkuman informasi pilihan. MIS berguna untuk efisiensi operasional. Laporan data, Monitoring layanan dan Customer relationship management, adalah bentuk sistem informasi pada Go-Jek yang memudahkan pihak manajemen mendapatkan data khusus, misal statistik dan data pemesanan dan transaksi dari user, ataupun kinerja dari driver atau suksesor layanan lainnya.

2. Decision Support Systems

Decision support systems (DSS) merupakan langkah selanjutnya dari MIS dan TPS. DSS adalah sistem informasi yang menggunakan model keputusan dan data khusus untuk membantu proses pengambilan keputusan bagi manajemen. Gunanya untuk mendukung pihak manajemen untuk memecahkan masalah tertentu dengan tepat. Data khusus dalam sistem informasi yang didapat dari pengumpulan data sebelumnya menjadi acuan manajer Go-Jek sebagai bahan keputusan untuk memusatkan atau mengekspansi usaha, penentuan dan rekruitmen driver atau suksesor layanan baru, serta pengembangan layanan.

3. Executive Information Systems

Executive information systems (EIS) adalah tipe sistem informasi yang sesuai untuk kebutuhan informasi bagi manajemen eksekutif. Tujuannya menyediakan dengan akses yang mudah dan cepat, tentang informasi selektif faktor-faktor kunci dalam menjalankan tujuan strategis perusahaan bagi manajemen eksekutif. Kemudian memberikan kebijakan perusahaan secara umum atau kebijakan yang diperuntukan pada level di bawah, yang kemudian akan di terjemahkan lebih spesifik oleh level di bawahnya dalam sistem informasi. 
Dalam EIS, eksekutif Go-Jek memanfaatkan sistem informasi untuk menentukan kebijakan bagi peningkatan keseluruhan perusahaan, seperti Penawaran Saham Perdana atau IPO agar potensi pertumbuhan lebih cepat, menjalin kerjasama dengan perusahaan lainnya, serta menganalisa kompetitor dan membuat kebijakan agar dapat bersaing.

\section{Teknologi Informasi yang digunakan}

Dalam memberikan layanan, Go-Jek memanfaatkan teknologi informasi, antara lain :

1. Teknologi End User

a. Aplikasi Smartphone Android

b. Aplikasi Smartphone IOS

2. Teknologi Database
a. Cloud Computing
b. Smartphone Storage

3. API (application programming interface)
a. Google Maps
b. Google Place
c. Transjakarta API
d. Apotikantar API

4. Payment

Go-Pay (Online Credit)

5. Customer Service
a. Social Media
b. Website
c. Call Center

\section{Syarat Minimal Kompetensi untuk Bergabung}

1. Pegawai

a. Minimal S1 (Jurusan Sesuai dengan Bidang) Untuk Manajer masing-masing bagian.

b. Minimal D3(Jurusan Sesuai dengan Bidang) Untuk karyawan Front Office, IT, Akuntansi, Pemasaran.

c. IPK minimal 3.00

d. Berpengalaman dibidangnya.

e. Mampu bekerja Tim.

f. Berpenampilan menarik.

g. Cepet, tanggap, Jujur dan Tanggung Jawab. 
2. Tukang Ojek

a. Tidak dibatasi minimal pendidkan yang paling penting Cepet, tanggap, Jujur dan Tanggung Jawab dan berpengalaman.

b. Mempunyai SIM C

c. Mampu mengendarai sepeda motor dengan baik.

d. Taat lalu lintas.

\section{Kualitas Pelayanan GO-JEK}

Sebagai Perusahaan jasa yang sangat menjunjung tinggi sebuah kualitas jasa yang berikan, Go-Jek memberikan kualitas Jasa yang baik seperti

1. Kehandalan

Go-jek mampu memberikan pelayanan yang dijanjikan dengan tepat, dan dapat dipercaya, tepat waktu seperti pelayanan 90 minute delivery anywhere in the city

2. Daya Tanggap

Go-jek siap dan tanggap untuk menangani respon permintaan pelanggan karena gojek melakukan sistem online dalam hal pelayanannya juga menyediakan pinjaman dana untuk konsumen yang menggunakan jasa belanja. Shop for food, ticket, medicine anything under Rp 1.000.000. motto go-jek "We'll pay for it first"

3. Assurance (Jaminan)

Dalam pelayanannya Gojek berusaha untuk membuat konsumen merasa aman dalam hal pemakaian jasa Go-jek, dan juga selalu sopan terhadap konsumen, Seperti: Transparent pricing, Free shower cap and masker, serta selalu mengutamakan kejujuran dan kepercayaan

4. Emphaty

Dalam hal ini Go-jek berusaha menjadikan konsumen seperti pathner dan juga menciptakan hubungan relasional yang baik dengan pelanggan.

5. Tangible

Go-jek Selalu memberikan fasilitas fisik yang memadai juga perlengkapan dan juga sarana komunikasi baik untuk driver ataupun pelanggan. Peralatan Modern : Sistem Online dan TI nya yang bisa di instal di smartphone

\section{Spirit yang Terkandung dalam Pengelolaan Go-Jek Menjadi Landasan Pengembangan Lembaga Pendidikan Islam dalam Era Revolusi Industri 4.0}

Pengelolaan atau manajemen pendidikan ialah proses perencanaan, pengorganisasian, memimpin, mengendalikan tenaga pendididikan, sumber daya pendidikan untuk mencapai tujan pendidikan, mencerdaskan kehidupan bangsa, mengembangkan manusia seutuhnya, yaitu 
manusia yang beriman, bertaqwa kepada tuhan Yang Maha Esa, berbudi pekerti yang luhur, memiliki pengetahuan, keterampilan, kesehatan jasmani dan rohani, kepribadian yang mantap, mandiri, serta bertanggung jawab kemasyarakat dan kebangsaan. ${ }^{17}$

Rumusan manajemen pendidikan tersebut memberikan deskrepsi bahwa untuk mencapai tujuan pendidikan diperlukan suatu perencanaan (rencana strategis), pengorganisasian, pemimpin yang inovatif, dan pemanfaatan secara maksimal sumber daya yang ada dalam lembaga tersebut. Untuk menjalankan manajemen tersebut diperlukan suatu spirit dan sistem sebagai roda atau anomali dan motor penggerak sekaligus menjadi daya tarik bagi konsumen atau masyarakat.

Capaian pengembangan dan kemajuan Go-Jek yang begitu pesat dan tidak membutuhkan waktu begitu lama ( \pm 8 tahun), menjadi inspirasi penulis untuk mengkaji dan menafsirkan sistem manajemen atau pengelolaan Go-Jek. Ada beberapa Spirit atau nilai yang dapat dijadikan landasan dalam pengembangan kelembangaan Pendidikan Islam, diantaranya sebagai berikut:

1. Akses Muda dan Terjangkau

Dalam merespon kebutuhan masyarakat sekarang ini, di era revolusi industri 4.0 yang pada umumnya masyarakat memiliki tingkat kesibukan yang cukup padat, maka pada umumnya masyarakat dalam memenuhi kebutuhannya termasuk kebutuhan pendidikan anaknya akan memilih lembaga pendidikan yang mudah diakses lewat sistem digital (on-line). Untuk menentukan pilihan orang tua dalam pendidikan anakanya tentu akan melihat profil lembaga pendidikan tersebut.

Lembaga pendidikan yang merespon keinginan masyarakat tersebut akan menyediakan akses lebih mudah, profil lembaga atau sekolah dapat diakses lewat media online, proses pendaftaran, proses pembelajaran, evaluasi dan pengawasan orang tua terhadap perkembangan anaknya dapat diakses secara on-line. Lembaga Pendidikan seperti ini, akan "diserbu" oleh konsumen atau masyarakat. Misalnya, hasil penelitian yang dilakukan Ratih Kusuma Ningtias (2015) tentang Modernisasi Sistem Pembelajaran Pendidikan Agama Islam di Lembaga Pendidikan Muhammadiyah dan Nahdhatul Ulama memberikan deskripsi bahwa lembagaga Pendidikan telah melakukan modernisasi sistem pembelajaran baik dari segi komponen-komponenya maupun usaha-usahanya. Penelitian ini mengambil lokus atau studi di Pesantren Karangasem dan Pesantren Sunan Drajat.

2. Pelayanan yang Prima/berkualitas

Salah satu unsur utama dalam penilaian masyarakat suatu lembaga termasuk lembaga Pendidikan adalah sistem layananannya. Pelayanan yang prima atau bermutu (ramah $=$ salam, 
senyum, sapa (3S), mudah/simpel, dan terjangkau) memberikan kesan tersendiri kepada konsumen atau masyarakat sehingga menarik hatinya untuk menyekolahkan anaknya di lembaga/sekolah tersebut.

3. Komponen Sistem Informasi yang Lengkap

Salah satu keunggulan dari Go-Jek adalah adalah memiliki sistem informasi yang cukup lengkap; baik bersifat perangkat keras maupun yang bersifat perangkat lunak yang berbasis data. Sehingga dengan adanya sistem informasi tersebut memudahkan pelanggan/konsumen untuk mengaksesnya. Hal ini juga atau sistem ini juga yang diperlukan dalam pengelolaan lembaga Pendidikan sehingga informasi tentang profil dan keunggulan lembaga dapat dikenal secara luas oleh masyarakat.

4. Membangun Sistem Jaringan (Net Working)

Dalam era digital sekarang ini yang disebut dengan era revolusi industri 4.0 merupakan suatu peluang untuk membagun dan mengembangkan jaringan secara luas. Lembaga pendidikan yang ingin maju dan berkembang harus membangun jaringan (net working) secara luas, melakukan kerja sama dengan berbagai bidang, saling mengisi dan melengkapi, berkembang dan maju bersama.

Sedang dalam pendekatan agama anjuran untuk membangun jaringan (silaturrabim) sebagai esensi diciptakannnya manusia (Qs. An-Nisa (4): 1) dan untuk saling mengenal (interaksi atau mengadakan muamalah/kerjasama) tanpa mengenal batas agama, suku dan bangsa (Qs. Al-Hujurat (49): 13). Kemudian dari segi manfaat dalam menjalin jaringan (networking=silaturrahmi) dapat dilihat dalam sabda Rasulullah saw., "bahwa barang siapa yang ingin dilapangkan rezkinya dan dipanjangkan umurnya, maka hendaklah ia menyambung tali silaturrahmi” (HR. Muttafaquh alaib).

Makna "dilapangkan rezkinya" apabila ditransfer dalam pengeloaan lembaga Pendidikan dapat dimaknai bahwa membangun jaringan (net-working=silaturrahmi) dapat mendatangkan berbagai manfaat dalam pengeloaan lembaga. Misalnya, suatu lembaga yang kekurangan SDM dan skill dapat kerja sama dengan lembaga yang memiliki SDM dan skill yang cukup dengan melakukan suatu orientasi/pelatihan. Atau lembaga tersebut kekurangan siswa/mahasiswa dapat mentransfer atau mengarahkan sebagian mahasiswanya ke lembaga yang kekurangan siswa/mahasiswanya.

Sedang makna "dipanjangkan umurnya", dalam perspektif pengelolaan lembaga, maka dapat dipahami bahwa lembaga yang menjalin jaringan (net-working=silaturrabmi) secara luas dan intensif akan maju dan berkembang seiring perkembangan zaman (panjang umur) dan 
dapat merespon perkembangan zaman tersebut dengan melakukan suatu inovatif yang berkesinambungan dan konsisten (istiqamah).

5. Menyediakan banyak Menu layanan Jasa

Tersedia banyaknya menu (pilihan) dalam layanan jasa dalam pengeloaan Go-Jek merupakan suatu langkah strategis untuk menarik pengguna (konsumen) untuk menggunakan layanan aplikasi Go-Jek. Sistem ini dapat ditransfer dalam pengeloaan Lembaga Pendidikan dengan membuka atau menyediakan banyak jurusan/program studi yang menjadi pilihan bagi masyarakat. Dengan membuka banyak jurusan atau program studi merupakan suatu langkah strategis untuk menarik banyak siswa/mahasiswa sebagai salah satu basis utama dalam pengeloaan lembaga pendidikan.

\section{Kesimpulan}

Kemajuan alat informasi dan komunikasi sekarang ini yang dikenal dengan zaman digital industri 4.0 diiringi dengan terjadinya transformasi sosial dalam setiap lini atau bidang kehidupan. Salah satu bidang utama dalam kehidupan adalah bidang pendidikan, majunya pendidikan ditandai dengan majunya sains dan teknologi. Kemajuan sains dan teknologi merupakan suatu landasan pembangunan dan kemajuan suatu bangsa.

Lahirnya perusahaan Go-jek merupakan suatu respon atas kebutuhan masyarakat untuk mendapatkan layanan yang prima (cepat, mudah, nyaman, dan terjangkau). Capaian pengembangan dan kemajuan Go-Jek yang dicapai sekarang ini tidak lepas kepada spirit yang terdapat dalam pengeloaan Go-Jek. spirit pengelolaan yang terdapat dalam Go-Jek dapat ditransfer dalam pengelolaan pengembangan kelembagaan Pendidikan, diantaranya, yaitu; akses muda dan terjangkau, pelayanan yang prima, komponen sistem informasi yang lengkap, memperluas sistem jaringan, membuka atau menyediakan banyak menu layanan (jurusan atau program studi).

\section{Referensi}

Al-Qur'an al-Karim

Aliansyah, Muhamad Agil. "Drama 12 jam larangan ojek online Menteri Jonan | merdeka.com"

Andreas, Damianus. "Go-Jek Sumbang Rp8,2 Triliun Per Tahun ke Perekonomian Indonesia dalam Tirto.ID". tirto.id

Ayuwuragil, Kustin. "Djarum Akui Ikut Suntik Dana ke Gojek". teknologi

Bakri, Maskuri. 2018. Inovasi dan Pendidikan dan Pembelajaran, Malang: CV. Kota Tua Jalan Sanan 2017. Formulasi dan Implementasi Kebijakan Pendidikan: analisis Kritis Terhadap Proses Pembelajaran, Surabaya: Visi Press

Kusumawati, Utami Diah. "12 Ribu Lebih Orang Dukung Petisi Tolak Larangan Ojek Daring"

188 | Tarbiyatuna: Jurnal Pendidikan Islam; Volume 13, Nomor 2, Agustus 2020, 170-189 
Lauer, Robert H., Persfektif Tentang Perubahan Sosial, Jakarta: Rineka Cipta, 1993.

Nugraha, Dadang, Transformasi Sistem Revolusi Industri 4.0, Workshop Technopreneurship "Road to TBIC 2019", 30 September 2018.

Prasetya, Eko. "Resmi, Menteri Jonan larang ojek dan taksi online beroperasi! | merdeka.com". merdeka.com

Prihadi, Susetyo Dwi. "Perbaiki Sistem IT, Gojek Akuisisi Startup Asal India".

Rahman, Adi Fida. "Alasan Go-Jek Ekspansi ke Vietnam dan Pakai Nama Go-Viet". detikinet

Savithri, Agnes. "Google Akui Investasi ke Gojek". teknologi

Tech in Asia Indonesia - Komunitas Online Startup di Asia". id.techinasia.com) 